\title{
Target specific post-harvest treatment by gamma radiation for the microbial safety of dried Melissa officinalis and Aloysia citrodora
}

\author{
Márcia Meneses ${ }^{\mathrm{a}, \mathrm{b}}$, Amilcar L. Antonio ${ }^{\mathrm{c}}$, Sandra Cabo Verde ${ }^{\mathrm{a},}$ \\ ${ }^{a}$ Centro de Ciências e Tecnologias Nucleares, Instituto Superior Técnico, Universidade de Lisboa, Portugal \\ ${ }^{\mathrm{b}}$ Escola Superior de Tecnologia da Saúde de Lisboa, Instituto Politécnico de Lisboa, Portugal \\ ${ }^{\mathrm{c}}$ Centro de Investigação de Montanha (CIMO), ESA, Instituto Politécnico de Bragança, Portugal
}

\section{A R T I C L E I N F O}

\section{Keywords:}

Irradiation processing

Product safety

Dried medicinal plants

Lemon balm

Lemon verbena

\begin{abstract}
A B S T R A C T
This study aimed to assess a specific gamma radiation dose to be applied as a post-harvest process to guarantee the microbial safety of two medicinal plants, Melissa officinalis and Aloysia citrodora. Dried plants treated with gamma radiation indicated that a dose of $5 \mathrm{kGy}$ could be applied as a post-harvest treatment process of M. officinalis and A. citrodora, assuring the microbial safety of dried medicinal plants and lowering the potentiality of deleterious effects on plants' quality attributes. This will enhance the safety and quality of the dried plants to be used as raw materials in industrial applications.
\end{abstract}

\section{Introduction}

The use of medicinal plants is perhaps the oldest method of handling with illnesses (Kosalec et al., 2009). Herbal products include a diversity of self-prescribed preparations of plant origin that may usually be categorized as food, dietary supplements, cosmetics, and herbal medicinal products, that revealed good nutritional properties highlighting their relevance for an enhanced human nutrition and health (Kosalec et al., 2009; C. Pereira et al., 2015). Specifically, Melissa officinalis and Aloysia citrodora are herbs mainly used as spices and medicinal plants. M. officinalis is traditionally used for their spasmolytic nervous sedative, antiviral and antioxidant activities, and beneficial effects on the brain, as a treatment for memory disorders (de Sousa et al., 2004). Regarding to $A$. citrodora, the leaves of this plant are described to possess digestive, antispasmodic, antipyretic, sedative and stomachic properties. It has traditionally been used in infusions for the treatment of asthma, cold, fever, flatulence, colic, diarrhea and indigestion (Valentão et al., 2002).

The consumption of natural products has become a public health problem, since these medicinal herbs are prepared using natural plants collected, dried and packaged without an effective hygienic and sanitary control. These plants present microbiological contamination and can host an extensive spectrum of microorganisms such as bacteria, fungi and viruses (Martins et al., 2001), which are transferred via air- and soil-borne vectors (Kneifel et al., 2002). In the pharmaceutical industry, the use of raw materials with high level of microbiological safety is a crucial requirement, since the microorganisms can contaminate the final product (de la Rosa et al., 1995). This is also important in the food industry, where microbiological decontamination provides a product with higher shelf life, while maintaining its quality (Kamat et al., 2003).

Currently, three methods can be used for the antisepsis of herbs, specifically steam, fumigation and irradiation. However, steam degrades light-weight leafy herbs, and ground products are difficult and occasionally impossible to handle in the steam system (Eiss, 2001). As for ethylene oxide gas, such disinfection method has been forbidden in the European Union and many other countries because it is a carcinogen when inhaled and it leaves harmful chemical residues (Chmielewski and Migdał, 2005; Katušin-Ražem et al., 2001). Food irradiation, namely by gamma rays, is increasingly recognized as an effective method in decreasing postharvest food losses, ensuring hygienic quality as an alternative to fumigation or steam, and facilitating wider trade in foodstuffs (Katušin-Ražem et al., 2001; Kim et al., 2000; Wen et al., 2008). The radiation processing, have the ability to inactivate microorganisms at ambient or near ambient temperatures, consequently avoiding the harmful effects that heat has on flavor, color, and nutrient value of food. Irradiation has the advantage that products are processed in the final packaging stage, decreasing the possibility of cross contamination until actual use by the consumer (Farkas, 2006). Food irradiation is legally permitted in 54 countries worldwide for microbiological control in spices and their powders (International Atomic Energy Agency, 2012). The European Union has approved the treatment of

\footnotetext{
* Corresponding author.

E-mail addresses: marcia17meneses@gmail.com (M. Meneses), amilcar@ipb.pt (A.L. Antonio), sandracv@ctn.tecnico.ulisboa.pt (S. Cabo Verde).
} 
dried aromatic herbs, spices, and vegetable seasonings with ionizing radiation at a maximum radiation dose of $10 \mathrm{kGy}$, but some countries, such as Australia and the United States, can use up to a $30 \mathrm{kGy}$ dose (Codex Alimentarius Commission, 2003; Commission of the European Union, 1999). There are several studies addressing the irradiation treatment and its effects on herbs stating the $10 \mathrm{kGy}$ as the required dose to attain food standards (Chmielewski and Migdał, 2005; Katušin-Ražem et al., 2001; Kim et al., 2000; Koseki et al., 2002; Kumar et al., 2010; E. Pereira et al., 2015a). Nevertheless, our previous studies on these dried aromatic plants demonstrated a strong dependence of the plant species and irradiation dose on the treatment effect on chemical parameters and bioactive indicators of aromatic plants, advising for accurate studies of any plant species to be considered for irradiation (E. Pereira et al., 2015b; Pereira et al., 2018, 2017, 2016). In this way, the literature is scarce on the assessment of the potentiality of reducing the established $10 \mathrm{kGy}$ treatment dose of dried plant products as raw materials, in order to target specific ionizing radiation doses, which can reduces quality deterioration and increase the economic profit. The aim of this study was to assess the inactivation patterns by gamma radiation of the microbiological population of two dried medicinal plants, Melissa officinalis and Aloysia citrodora, in order to propose a target specific gamma radiation dose to be applied as post-harvest treatment of these two plants to guarantee the microbiological quality requirements of pharmaceutical and food industries.

\section{Materials and methods}

\subsection{Samples}

Samples of Melissa officinalis L. (Lamiaceae; lemon balm) and Aloysia citrodora P. (Verbenaceae; lemon verbena) were provided as dry leaves by a local producer (Pragmático Aroma Lda, Alfândega da Fé, Bragança, Portugal). After confirmation of the taxonomical identification, the samples were divided into groups: control (non-irradiated, $0 \mathrm{kGy}$ ) and irradiated groups at the several predicted doses (detailed in irradiation process).

\subsection{Irradiation process}

Irradiations were carried out at the Co-60 experimental equipment (Precisa 22, Graviner, Lda, UK) with total activity $165 \mathrm{TBq}(4.4 \mathrm{kCi})$ in December 2014, located at the Campus Tecnológico e Nuclear, Sacavém, Portugal. Dosimetric studies using the reference Fricke dosimeter were carried out in the irradiation facility in order to determine the best geometry and dose rate for the irradiation process $(1.3 \mathrm{kGy} / \mathrm{h})$.

For the natural microbiota inactivation studies, three packages of $1 \mathrm{~g}$ of dried $M$. officinalis and A. citrodora were irradiated at three estimated doses: $0.98 \pm 0.01 \mathrm{kGy} ; 2.87 \pm 0.06 \mathrm{kGy}$ and $5.40 \pm 0.14 \mathrm{kGy}$, in three irradiation batches for each plant. Three samples of $1 \mathrm{~g}$ of each plant were not submitted to irradiation (non-irradiated samples). Throughout the text, we considered the treatment doses as 1, 3 and $5 \mathrm{kGy}$ and $0 \mathrm{kGy}$ as non-treated (non-irradiated, control).

Regarding the challenging tests, the artificially contaminated dried plant samples $(1 \mathrm{~g})$ were irradiated at doses $0.49 \pm 0.07 \mathrm{kGy} ; 0.99 \pm$ $0.08 \mathrm{kGy}$ and $1.22 \pm 0.08 \mathrm{kGy}$ (3 packages of $1 \mathrm{~g}$ each per radiation dose) in three independent irradiation batches for each plant. Nonirradiated spiked samples $(n=3)$ followed the assays.

The absorbed dose was monitored using calibrated routine dosimeters (uncertainty of $\pm 2.5 \%$; Perspex, Harwell, UK) to estimate the radiation doses absorbed by the product. The obtained average dose uniformity (maximum dose/minimum dose) was 1.04 .

\subsection{Inactivation studies of the natural microbiota of medicinal plants}

The microbial load of the selected plants was estimated before and after irradiation by a filtration technique. Non-irradiated and irradiated samples were blended on $100 \mathrm{ml}$ of saline solution with a tensioactive agent $(0.9 \% \mathrm{NaCl}$ with $0.1 \%$ Tween 80$)$ and homogenized in stomacher blender equipment (Stomacher 3500; Seaward, UK) during $15 \mathrm{~min}$. Aliquots of $10 \mathrm{ml}$ of plants washing solution were filtrated in triplicate using nitrocellulose membranes with a pore size of $0.45 \mu \mathrm{m}$ (Sartorious AG, Germany). The membranes were placed into petri dishes containing Tryptic Soy Agar (TSA) media for bacterial quantification and into Malt Extract Agar (MEA) media for fungal assessment. TSA and MEA petri dishes were incubated during 7 days at aerobic atmosphere at $30^{\circ} \mathrm{C}$ and $28^{\circ} \mathrm{C}$, respectively.

Microbiological counts were expressed as mean log colony-forming units (CFU) per gram. The natural microbiota of non-irradiated and irradiated plants samples was morphologically and biochemically characterized. Isolates were divided in eleven morphological types based on macroscopic (e.g. pigmentation, texture, shape), microscopic (e.g. cellular morphology, endospores presence/absence) and biochemical characteristics (e.g. gram staining, catalase and oxidase activities). The definition of the eleven morphological types was based on the Bergey's Manual of Determinative Bacteriology (Holt et al., 1994). The frequency of each morphological type was calculated based on the number of isolates and its characterization.

For fungal identification, microscopic mounts were performed using tease mount or Scotch tape mount and lactophenol cotton blue mount procedures. Morphological Identification was achieved through macro and microscopic characteristics as noted by Atlas of Clinical Fungi (Hoog et al., 2000).

\subsection{Challenging test with Escherichia coli}

Samples of $1 \mathrm{~g}$ of each medicinal plant, in triplicate, were artificially contaminated with $10^{5} \mathrm{CFU} / \mathrm{g}$ of a pure culture of Escherichia coli (ATCC 8739) and then allowed to dry for $15 \mathrm{~min}$. Thereafter, the non-irradiated and irradiated samples were blended on $100 \mathrm{ml}$ of saline solution with a tensioactive agent $(0.9 \% \mathrm{NaCl}$ with $0.1 \%$ Tween 80$)$ and homogenized in stomacher blender equipment (Stomacher 3500; Seaward, UK) during $15 \mathrm{~min}$. E. coli counts were carried out in triplicate onto Violet Red Bile Agar (VRB-Agar; Merck) at $30^{\circ} \mathrm{C}$ for 7 days, and expressed as mean log colony-forming units (CFU) per gram.

\subsection{Data analysis}

Origin software version 7.5 (OriginLab Corporation, Northampton, USA) was used for data analysis. The D10 value represents the dose that achieves a $90 \%(1-\log )$ reduction of the target bacteria. The surviving E. coli concentration ( $\log \mathrm{CFU} / \mathrm{g}$ ) was plotted as a function of the measured gamma radiation dose (kGy). Linear regression analysis was performed, and the negative reciprocal of the slope was calculated to be the D10 value.

\section{Results}

The microbiological counts indicated that $M$. officinalis presented a low average bioburden of $2.50 \pm 0.02 \mathrm{log} \mathrm{CFU} / \mathrm{g}$. The mesophilic microbial population of this dried plant followed a linear gamma radiation inactivation kinetics, with an inactivation efficiency of $88 \%$ for $5 \mathrm{kGy}$, which corresponds to a $0.9 \log$ cycle reduction in microbial total counts (Fig. 1). Concerning to $A$. citrodora, the results also indicated a reduced initial bioburden of $2.62 \pm 0.02 \mathrm{log} \mathrm{CFU} / \mathrm{g}$. The microbial inactivation efficiency obtained was $94 \%$ for $5 \mathrm{kGy}$. Regarding the filamentous fungi population, $M$. officinalis showed a fungal population concentration of $1.47 \pm 0.05 \log \mathrm{CFU} / \mathrm{g}$, while $A$. citrodora presented a fungal load of $1.37 \pm 0.01 \log \mathrm{CFU} / \mathrm{g}$. However, both fungal populations showed a nonlinear inactivation kinetic curve. A reduction of $0.5 \mathrm{log}$ for the fungal populations was achieved for $5 \mathrm{kGy}$, corresponding to an inactivation efficiency of approximately $70 \%$ (Fig. 1).

The microbiota from non-irradiated and irradiated of $M$. officinalis 
A)

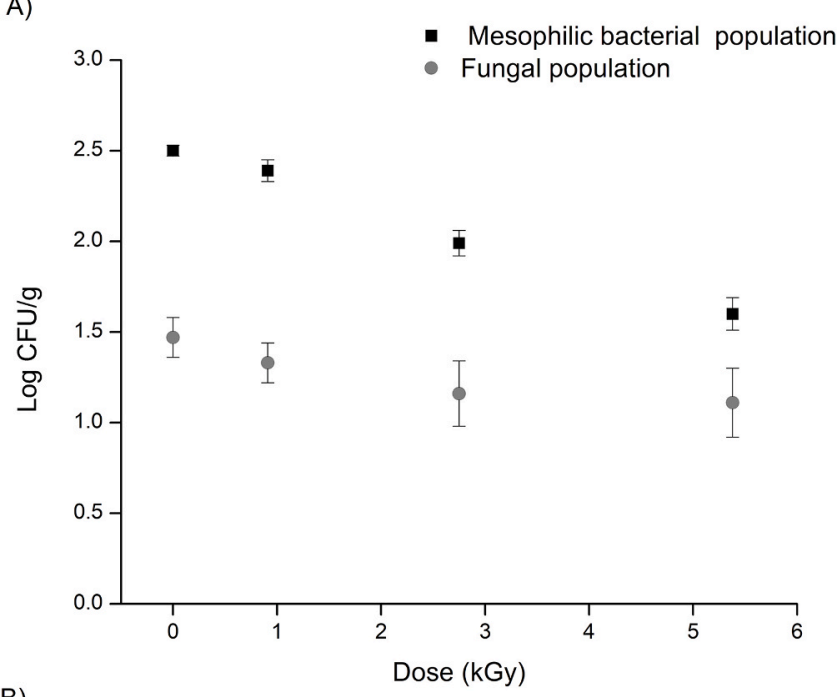

B)

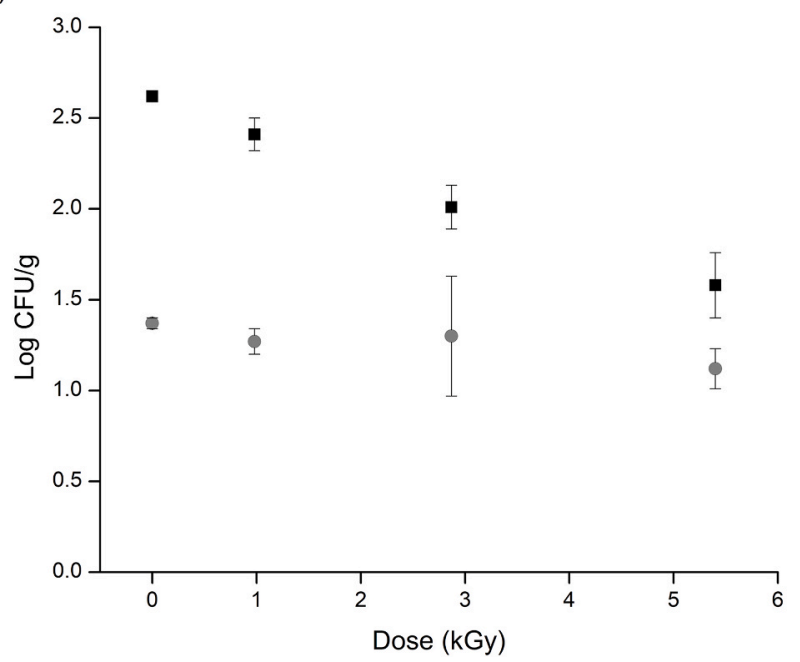

Fig. 1. Gamma radiation survival curve for the mesophilic bacterial and fungal populations of medicinal plants: (A) Melissa officinalis and (B) Aloysia citrodora. Error bars correspond to $95 \%$ confidence intervals about mean values ( $n=18$; $\alpha=0.05)$.

and $A$. citrodora were phenotypically characterized to assess the dynamics of their microbial community and its patterns with ionizing radiation doses (Table 1 ).

The microbiota of $M$. officinalis was mostly constituted by Grampositive catalase-positive rods (68\%) and Gram-negative oxidase-negative rods (22\%). Regarding the natural microbiota of $A$. citrodora, the major phenotypes isolated were also the Gram-positive catalase-positive rods (54\%) and Gram-negative oxidase-negative rods (40\%).

The predominant morphological types of surviving microbiota of irradiated $M$. officinalis were the Gram-positive catalase-positive rods
(65\%) and filamentous fungi (19\%). After irradiation, the morphotypes of the microbial population of A. citrodora were mainly the Gramnegative oxidase-negative rods (53\%) and Gram-positive catalase-positive rods (35\%). Among fungal population from non-irradiated samples of $M$. officinalis, the genus Aspergillus was the most isolated (57\%), followed by Penicillium (22\%) and Alternaria (8\%). Concerning gamma radiation-surviving fungi, the most frequently found was Alternaria spp. (57\%) and Uloclaudium spp. (11\%) at the higher applied irradiation dose of $5 \mathrm{kGy}$ (Table 2). The initially predominant fungal genera Aspergillus and Penicillium decreased its prevalence with the increment of gamma radiation dose, and were not detected in $M$. officinalis after a $5 \mathrm{kGy}$ treatment dose. In non-irradiated and irradiated samples ( 1 kGy, 3 kGy and $5 \mathrm{kGy}$ ) it was also detected countless colonies of Mucor spp. The fungal population of $A$. citrodora was mainly constituted by Alternaria spp. (55\%) and Aspergillus spp. (13\%). The identification of the surviving fungi from this irradiated dried plant presented the genus Alternaria as the prevalent (Table 2).

Countless colonies of Neoscytalidium spp. and Mucor spp. were also found in non-irradiated and irradiated samples. Among the Aspergillus genus, the fungal species that were more abundant in non-irradiated samples of $M$. officinalis were Aspergillus niger (39\% of natural fungal population) and Aspergillus fumigatus (16\% of fungal population). Also, in non-irradiated samples of $A$. citrodora, the fungi Aspergillus niger $(11 \%$ of fungal population) and Aspergillus fumigatus ( $\%$ of fungal population) were isolated.

When a suspension of a microorganism is irradiated at incremental doses, the number of surviving Colony Forming Units (CFUs) after each incremental dose may be used to construct a dose-survival curve. Microbial radiation survival follows in most cases a linear inactivation kinetics. This linear correlation between the absorbed dose D (kGy) and the bacteria survival number $\mathrm{N}$ (CFU/g) is represented by $\log N=k \cdot D+$ $\log N_{0}$, in which the D10 value is the inverse slope (k) of the obtained regression line and $\mathrm{N}_{0}$ is the initial bioburden. The challenging tests of M. officinalis and A. citrodora with Escherichia coli (ATCC 8739) indicated for both plants a linear inactivation kinetics $\left(\mathrm{R}^{2}=0.990\right.$ for $M$. officinalis and $\mathrm{R}^{2}=0.987$ for $A$. citrodora) of this bacteria by gamma radiation (Fig. 2). Based on this, the dose required to achieve $90 \%$ reduction, the D10 value, for E.coli in $M$. officinalis and A. citrodora was estimated to be $0.54 \pm 0.04 \mathrm{kGy}$ and $0.39 \pm 0.03 \mathrm{kGy}$, respectively.

\section{Discussion}

In the current study, the results indicated a low total aerobic plate counts for $M$. officinalis and A. citrodora of approximately $2.5 \log \mathrm{CFU} / \mathrm{g}$. The total aerobic plate counts that have been reported for other botanical raw materials ranged between 3 and $8 \mathrm{log} \mathrm{CFU} / \mathrm{g}$ (Kumar et al., 2010). The natural microbiota of the herbs could be attributed to several factors such as the general conditions during their cultivation, harvesting, drying, handling, processing, storage, distribution and sales. However, it was described that the microbial status of dried herbal material is not so much caused by secondary contamination during processing, but may mainly be due to the fact that plants have their specific microbial flora (Donia, 2008). The good manufacturing practices applied in the processing of the analyzed plant products could

Table 1

Relative frequency of the phenotypes of the isolates from non-irradiated and irradiated medicinal plants at several gamma radiation doses.

\begin{tabular}{|c|c|c|c|c|c|c|c|c|}
\hline \multirow[t]{3}{*}{ Phenotypic group } & \multicolumn{8}{|c|}{ Percentage relative to total microbiota (\%) } \\
\hline & \multicolumn{4}{|c|}{ Melissa officinalis } & \multicolumn{4}{|l|}{ Aloysia citrodora } \\
\hline & Non-irradiated & $1 \mathrm{kGy}$ & $3 \mathrm{kGy}$ & $5 \mathrm{kGy}$ & Non-irradiated & $1 \mathrm{kGy}$ & $3 \mathrm{kGy}$ & $5 \mathrm{kGy}$ \\
\hline Gram-positive, catalase-positive rods & 67.9 & 79.1 & 57.9 & 64.6 & 54.1 & 33.5 & 34.3 & 35.2 \\
\hline Gram-negative, oxidase-negative rods & 21.6 & 12.5 & 32.9 & 16.7 & 40.0 & 52.7 & 46.5 & 52.8 \\
\hline Gram-negative, catalase-positive cocci & 0.0 & 0.0 & 0.0 & 0.0 & 0.0 & 7.6 & 3.3 & 3.6 \\
\hline Gram-positive, catalase-positive cocci & 0.0 & 0.0 & 0.0 & 0.0 & 0.1 & 0.0 & 0.0 & 1.0 \\
\hline Filamentous fungi & 10.4 & 8.4 & 9.2 & 18.8 & 5.7 & 6.2 & 15.9 & 7.4 \\
\hline
\end{tabular}


Table 2

Most common fungal genera identified in non-irradiated and irradiated samples of medicinal plants.

\begin{tabular}{|c|c|c|c|c|c|c|c|c|}
\hline \multirow[t]{3}{*}{ Fungi } & \multicolumn{8}{|c|}{ Percentage relative to total fungal population (\%) } \\
\hline & \multicolumn{4}{|c|}{ Melissa officinalis } & \multicolumn{4}{|l|}{ Aloysia citrodora } \\
\hline & Non-irradiated & $1 \mathrm{kGy}$ & 3 kGy & 5 kGy & Non-irradiated & $1 \mathrm{kGy}$ & $3 \mathrm{kGy}$ & $5 \mathrm{kGy}$ \\
\hline Aspergillus spp. & 56.6 & 47.5 & 21.7 & ND & 12.5 & 9.5 & ND & ND \\
\hline Penicillium spp. & 21.7 & 1.7 & ND & ND & 1.8 & 2.4 & ND & ND \\
\hline Alternaria spp. & 8.4 & 11.9 & 16.4 & 56.5 & 55.4 & 66.7 & 82.1 & 91.3 \\
\hline Ulocladium spp. & ND & ND & 7.0 & 10.7 & 10.7 & 2.4 & 14.8 & ND \\
\hline Others $^{\mathrm{a}}$ & 13.3 & 38.9 & 54.9 & 32.8 & 19.6 & 19.0 & 3.1 & 8.7 \\
\hline
\end{tabular}

ND - not detected.

${ }^{\text {a }}$ Percentage of fungal isolates at a relative frequency $<5 \%$ of total fungal population.

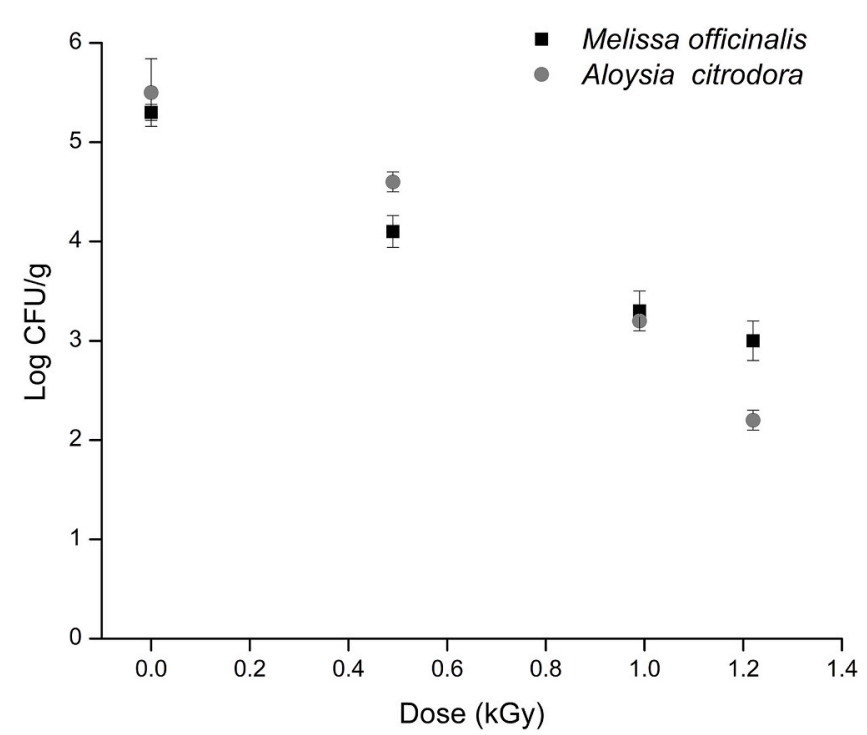

Fig. 2. Gamma radiation survival curve for inoculated Escherichia coli (ATCC 8739) into medicinal plants: Melissa officinalis (black squares) and Aloysia citrodora (grey circles). Error bars correspond to $95 \%$ confidence intervals about mean values ( $\mathrm{n}=18 ; \alpha=0.05)$.

explain the low microbial loads obtained. However, to fulfill the requirements of health and food industries regarding raw materials, lower microbial loads must be attained (Bomblies et al., 2007; Daelman et al., 2013). Some studies have revealed that radiation processing can be an effective technique for the decontamination of some medicinal plants (Chmielewski and Migdał, 2005; Katušin-Ražem et al., 2001; Kim et al., 2000; Koseki et al., 2002; Kumar et al., 2010). The inactivation kinetics of natural microbiota of the two dried plants was assessed indicating to be a linear inactivation survival curve. Based on the obtained linear regression models it could be estimated a reduction of approximately 1 $\log$ on the aerobic bacterial populations of these medicinal plants after irradiation at $5 \mathrm{kGy}$. The effectiveness of irradiation treatment depends on different factors, including composition of food, number and type of microorganisms, and applied dose (Farkas, 2006). The applied gamma radiation dose range ( $1 \mathrm{kGy}$ up to $5 \mathrm{kGy}$ ) was selected with the intent to assess the potential use of radiation doses below $10 \mathrm{kGy}$ in order to assure the microbiological safety of tested plant products while maintaining their qualities. Our previous studies indicated that gamma radiation and electron beam to a dose of $10 \mathrm{kGy}$ could induce effects in the chemical/nutritional and antioxidant properties of A. citrodora and M. officinalis (E. Pereira et al., 2015a; 2015b; Pereira et al., 2018, 2017, 2016). Nonetheless, the performed analysis under an integrated approach indicated that irradiation treatment did not cause sufficient changes to define a specific chemical profile for the analyzed plants. Moreover, low dose gamma radiation for extension of shelf life, microbiological safety and retention of quality indices in minimally processed vegetables and fruits are increasingly gaining importance for industry, restaurants, institutional and airline catering (Farkas, 2006).

The obtained microbial load reduction could be related to the types of microorganism that constitute the $M$. officinalis and A. citrodora microbiota. According to different studies on medicinal plants microbiota, the predominant bacteria are Escherichia coli, Shigella spp., Salmonella spp., Bacillus subtilis and Staphylococcus aureus (Chmielewski and Migdał, 2005; Idu et al., 2010; McKee, 1995; Sospedra et al., 2010). In the current study, the morphological characterization of the natural microbiota of $M$. officinalis and A. citrodora indicated as predominant morphological types the Gram-positive catalase positive rods, which includes the microorganisms of genus Bacillus; and the Gram-negative oxidase-negative rods, where microorganisms of genera Escherichia, Salmonella and Shigella can be comprised. According to literature, bacteria from Enterobacteriacea family are relatively sensitive to irradiation and, in most cases, a dose of about $5 \mathrm{kGy}$ is sufficient for their elimination (Farkas, 2006). However, the obtained surviving microbial population phenotypes' did not agree with the ones reported previously, probably due to a protective effect of plants substrate. Suspending medium may contain certain compounds that act as protective agents (compounds that are known as scavengers) which give protection against irradiation damage (Farkas, 2006). Moreover, the radiation induced damage by the free radical produced by water radiolysis could not be considered, since the plants are dried, this fact also leads to an increased radioresistance.

Escherichia coli was one of the most reported bacteria present in natural microbiota of herbs, for this reason and because of its potential health effects, becomes crucial to study the gamma radiation as a processing method for the disinfection of this bacteria (Idu et al., 2010; McKee, 1995). Extrapolating the obtained $E$. coli inactivation results to a dose of $5 \mathrm{kGy}$, it will be expected a reduction of approximately 9-12 log $\mathrm{CFU} / \mathrm{g}$ of $E$. coli load on the analyzed dried plants (in practice a disinfection). According to other study, the D10 value for E.coli is between 0.20 and $0.65 \mathrm{kGy}$, which is in agreement with the results obtained in this study for both medicinal plants (Trampuz, 2006).

Regarding fungal population, several studies demonstrated that the most frequent fungi found in different medicinal plants were Aspergillus sp., Penicillium sp., Mucor sp. and Cladosporium sp., supporting the obtained results from both analyzed dried plants (de la Rosa et al., 1995; Donia, 2008). Fungi in general are considered more resistant than the vegetative forms of bacteria (Aquino, 2011). In the present study, it was observed a low inactivation rate for the fungal population of both plants corresponding to a decrease of $0.5 \mathrm{log}$ on fungal load after irradiation at $5 \mathrm{kGy}$. The sensitivity of fungi to gamma radiation was determined in various studies (Aquino, 2011; Aquino et al., 2010; Iqbal et al., 2012). Nevertheless, there are some genera of filamentous fungi, specifically Aspergillus and Penicillium, presenting intermediate resistance, and genus such as Alternaria that can present a high radiation resistance due to the multi-cellularity of spores (Aquino, 2011; Iqbal et al., 2012). Supporting other studies results, the occurrence of Aspergillus sp. and Penicillium sp. decreases with the increase of irradiation dose and at $5 \mathrm{kGy}$ the presence of these genera of fungi is not detected (Iqbal et al., 2012). However, 
there is some fungus genus, which indicated to be resistant to irradiation such as Alternaria sp., since isolates were detected at $5 \mathrm{kGy}$ in both medicinal plants samples. Other authors, have also shown a higher resistance of dematiaceous fungi (Alternaria alternata, Cladosporium cladosporioides, Curvularia lunata, etc.) to gamma radiation (Aquino, 2011). Some investigators suggested that filamentous fungi produce numerous metabolites as protective agents, such as alcohols, acids, enzymes, pigments, polysaccharides, and steroids, as well as some complex compounds, such as ergotinine, and antibiotics, including penicillin, notatin, flavicin, and fumigacin (Aquino, 2011). In addition, intracellular fungal components (sulfhydric compounds, pigments, amino acids, proteins and fatty acids) have been reported to be responsible for radioresistance of fungi (Aquino, 2011). As reported elsewhere, to reduce fungal contamination in medicinal plants, an average dose of $5 \mathrm{kGy}$ was enough to decrease the counts to acceptable levels (Aquino, 2011; Aquino et al., 2010; Iqbal et al., 2012).

It is generally assumed that microbial resistance to gamma radiation depends on many factors, combining intrinsic factors as the individual sensibility with other external factors as the radioprotection/sensitization effect of substrate compounds (Aquino, 2011). In this study, low inactivation rates (reduction of $1 \log \mathrm{CFU} / \mathrm{g}$ ) by gamma radiation were obtained for the microbial populations of $M$. officinalis and A. citrodora after a gamma radiation treatment of $5 \mathrm{kGy}$. However, this apparent low reduction, is sufficient to guarantee the restrictive acceptance criteria for microbiological quality (e.g. total aerobic counts $<10^{2} \mathrm{CFU} / \mathrm{g}$ and total fungal counts $<10^{1} \mathrm{CFU} / \mathrm{g}$ ) of pharmaceutical preparations (Council of Europe, 2010). In addition, the results obtained indicated that a gamma radiation dose of $5 \mathrm{kGy}$ could be applied as a postharvest treatment process of $M$. officinalis and A. citrodora, lowering the potentiality of deleterious effects on plants' quality attributes. In general, better knowledge of the effect of preservation agents on microorganisms would lead to a more rational design of processes, being essential for the development of safe products (Nemţanu et al., 2014). This study highlight the significance of the assessment of a treatment dose for each individual application that should established, taking into consideration the contamination level, the hazards involved, oxygen presence, the substrate effect, possible storage conditions and the efficiency of the radiation to the intended treatment objective.

\section{Compliance with ethical standards}

This article does not contain any studies with human or animal subjects performed by any of the authors.

\section{Declaration of competing interest}

The authors declare that they have no known competing financial interests or personal relationships that could have appeared to influence the work reported in this paper.

\section{Acknowledgements}

The authors are grateful to project PRODER $n^{\circ}$ 53515, AROMAP, for financial support of the work. The authors thank to "MaisErvas Aromáticas e Medicinais" company for supplying the samples. C2TN/ IST authors gratefully acknowledge the FCT support through the RECI/ AAG-TEC/0400/2012 and UID/Multi/04349/2013 projects.

\section{Appendix A. Supplementary data}

Supplementary data to this article can be found online at https://doi. org/10.1016/j.apradiso.2020.109391.

\section{References}

Aquino, S., 2011. Gamma radiation against toxigenic fungi in food, medicinal and aromatic herbs. In: Science against Microbial Pathogens: Communicating Current Research and Technological Advances, pp. 272-281.

Aquino, S., Gonçalez, E., Rossi, M.H., Nogueira, J.H., Reis, T.A., Corrêa, B., 2010. Evaluation of fungal burden and aflatoxin presence in packed medicinal plants treated by gamma radiation. J. Food Protect. 73, 932-937.

Bomblies, L., Weiss, C., Beckmann, G., 2007. Examination of microbiological quality of pharmaceutical raw materials. Pharmeur Sci Notes 2007, 1-7.

Chmielewski, A.G., Migdał, W., 2005. Radiation decontamination of herbs and spices. Nukleonika 50, 179-184.

Codex Alimentarius Commission, 2003. General Standard for Irradiated Foods, pp. 1-10. Commission of the European Union, 1999. Directive 1999/3/EC of 22 February 1999 on the Establishment of a Community List of Foods and Food Ingredients Treated with Ionizing Radiation.

Council of Europe, 2010. European Pharmacopoeia. Strasbourg.

Daelman, J., Jacxsens, L., Lahou, E., Devlieghere, F., Uyttendaele, M., 2013. Assessment of the microbial safety and quality of cooked chilled foods and their production process. Int. J. Food Microbiol. 160, 193-200. https://doi.org/10.1016/j. ijfoodmicro.2012.10.010.

de la Rosa, M. del C., Rosario Medina, M. del, Vivar, C., 1995. Microbiological quality of pharmaceutical raw materials. Pharm. Acta Helv. 70, 227-232. https://doi.org/ 10.1016/0031-6865(95)00022-2.

de Sousa, A.C., Alviano, D.S., Blank, A.F., Alves, P.B., Alviano, C.S., Gattass, C.R., 2004. Melissa officinalis L. essential oil: antitumoral and antioxidant activities. J. Pharm. Pharmacol. 56, 677-681. https://doi.org/10.1211/0022357023321.

Donia, M.A.A., 2008. Microbiological quality and aflatoxinogenesis of Egyptian spices and medicinal plants. Global Vet. 2, 175-181.

Eiss, I., 2001. Growing impact of irradiation on global production of and trade in spices. In: Loaharanu, P., Thomas, P. (Eds.), Growing Impact of Irradiation on Global Production of and Trade in Spices. Technomic, Vienna, pp. 178-191.

Farkas, J., 2006. Irradiation for better foods. Trends Food Sci. Technol. 17, 148-152. https://doi.org/10.1016/j.tifs.2005.12.003.

Holt, J.H., Krieg, N.R., Sneath, P.H.A., Staley, J.T., Williams, S.T., 1994. Bergey's Manual of Determinative Bacteriology, ninth. Williams and Wilkins Editors, Baltimore.

Hoog, C., Guarro, J., Gené, G., Figueras, M., 2000. Atlas of Clinical Fungi - the Ultimate Benchtool for Diagnostics, second. Centraalbureau voor Schimmelcultures, Utrecht.

Idu, M., Erhabor, J.O., Efijuemue, H.M., 2010. Documentation on medicinal plants sold in markets in Abeokuta, Nigeria. Trop. J. Pharmaceut. Res. 9, 110-118. https://doi. org/10.4314/tjpr.v9i2.53696.

International Atomic Energy Agency, 2012. Food Irradiation Clearance Database [WWW Document].

Iqbal, Q., Amjad, M., Asi, M.R., Ariño, A., 2012. Mold and aflatoxin reduction by gamma radiation of packed hot peppers and their evolution during storage. J. Food Protect. 75, 1528-1531. https://doi.org/10.4315/0362-028X.JFP-12-064.

Kamat, A., Pingulkar, K., Bhushan, B., Gholap, A., Thomas, P., 2003. Potential application of low dose gamma irradiation to improve the microbiological safety of fresh coriander leaves. Food Contr. 14, 529-537. https://doi.org/10.1016/S09567135(02)00116-0.

Katušin-Ražem, B., Novak, B., Ražem, D., 2001. Microbiological decontamination of botanical raw materials and corresponding pharmaceutical products by irradiation. Radiat. Phys. Chem. 62, 261-275. https://doi.org/10.1016/S0969-806X(01)001906.

Kim, M.J., Yook, H.S., Byun, M.W., 2000. Effects of gamma irradiation on microbial contamination and extraction yields of Korean medicinal herbs. Radiat. Phys. Chem. 57, 55-58. https://doi.org/10.1016/S0969-806X(99)00298-4.

Kneifel, W., Czech, E., Kopp, B., 2002. Microbial contamination of medicinal plants-a review. Planta Med. 68, 5-15. https://doi.org/10.1055/s-2002-20060.

Kosalec, I., Cvek, J., Tomić, S., 2009. Contaminants of medicinal herbs and herbal products. Arh. Hig. Rada. Toksikol. 60, 485-501. https://doi.org/10.2478/100041254-60-2009-2005.

Koseki, P.M., Villavicencio, A.L.C.H., Brito, M.S., Nahme, L.C., Sebastião, K.I., Rela, P.R., Almeida-Muradian, L.B., Mancini-Filho, J., Freitas, P.C.D., 2002. Effects of irradiation in medicinal and eatable herbs. Radiat. Phys. Chem. 63, 681-684. https://doi.org/10.1016/S0969-806X(01)00658-2.

Kumar, S., Gautam, S., Powar, S., Sharma, A., 2010. Microbial decontamination of medicinally important herbals using gamma radiation and their biochemical characterisation. Food Chem. 119, 328-335. https://doi.org/10.1016/j. foodchem.2009.06.034.

Martins, H.M., Martins, M.L., Dias, M.I., Bernardo, F., 2001. Evaluation of microbiological quality of medicinal plants used in natural infusions. Int. J. Food Microbiol. 68, 149-153. https://doi.org/10.1016/S0168-1605(01)00480-9.

McKee, L.H., 1995. Microbial contamination of spices and herbs: a review. LWT - Food Sci. Technol. (Lebensmittel-Wissenschaft -Technol.) 28, 1-11. https://doi.org/ 10.1016/S0023-6438(95)80004-2.

Nemțanu, M.R., Brașoveanu, M., Karaca, G., Erper, I., 2014. Inactivation effect of electron beam irradiation on fungal load of naturally contaminated maize seeds. J. Sci. Food Agric. 94, 2668-2673. https://doi.org/10.1002/jsfa.6607.

Pereira, C., Barros, L., Ferreira, I.C.F.R., 2015. A comparison of the nutritional contribution of thirty-nine aromatic plants used as condiments and/or herbal infusions. Plant Foods Hum. Nutr. 70, 176-183. https://doi.org/10.1007/s11130015-0476-7.

Pereira, E., Antonio, A.L., Barreira, J.C.M., Barros, L., Bento, A., Ferreira, I.C.F.R., 2015a. Gamma irradiation as a practical alternative to preserve the chemical and bioactive 
wholesomeness of widely used aromatic plants. Food Res. Int. 67, 338-348. https:// doi.org/10.1016/j.foodres.2014.11.047.

Pereira, E., Antonio, A.L., Barreira, J.C.M., Verde, S.C., Barros, L., Oliveira, M.B.P.P., Ferreira, I.C.F.R., 2018. Evaluation of gamma-irradiated aromatic herbs: chemometric study of samples submitted to extended storage periods. Food Res. Int. https://doi.org/10.1016/j.foodres.2018.05.051.

Pereira, E., Antonio, A.L., Rafalski, A., Barreira, J.C.M., Barros, L., Ferreira, I.C.F.R., 2015b. Extending the use of irradiation to preserve chemical and bioactive properties of medicinal and aromatic plants: a case study with four species submitted to electron beam. Ind. Crop. Prod. 77, 972-982. https://doi.org/10.1016/j. indcrop.2015.09.073.

Pereira, E., Barros, L., Antonio, A.L., S, C.V., Santos-Buelga, C., Ferreira, I.C., Rodrigues, P., 2017. Is gamma radiation suitable to preserve phenolic compounds and to decontaminate mycotoxins in aromatic plants? A case-study with Aloysia citrodora paláu. https://doi.org/10.3390/molecules22030347.

Pereira, E., Pimenta, A.I., Calhelha, R.C., Antonio, A.L., Cabo Verde, S., Barros, L., Santos-Buelga, C., Ferreira, I.C.F.R., 2016. Effects of gamma irradiation on cytotoxicity and phenolic compounds of Thymus vulgaris L. and Mentha x piperita L. LWT - Food Sci. Technol. (Lebensmittel-Wissenschaft -Technol.). https://doi.org/ 10.1016/j.lwt.2016.04.004.

Sospedra, I., Soriano, J.M., Mañes, J., 2010. Assessment of the microbiological safety of dried spices and herbs commercialized in Spain. Plant Foods Hum. Nutr. 65, 364-368. https://doi.org/10.1007/s11130-010-0186-0.

Trampuz, A., 2006. Effect of gamma irradiation on viability and DNA of Staphylococcus epidermidis and Escherichia coli. J. Med. Microbiol. 55, 1271-1275. https://doi. org/10.1099/jmm.0.46488-0.

Valentão, P., Fernandes, E., Carvalho, F., Andrade, P.B., Seabra, R.M., de Lourdes Bastos, M., 2002. Studies on the antioxidant activity of Lippia citriodora infusion: scavenging effect on superoxide radical, hydroxyl radical and hypochlorous acid. Biol. Pharm. Bull. 25, 1324-1327. https://doi.org/10.1248/bpb.25.1324.

Wen, H.W., Chung, H.P., Wang, Y.T., Hsieh, P.C., Lin, I.H., Chou, F.I., 2008. Efficacy of gamma irradiation for protection against postharvest insect damage and microbial contamination of adlay. Postharvest Biol. Technol. 50, 208-215. https://doi.org/ 10.1016/j.postharvbio.2008.05.009. 